\title{
Peningkatan Kemampuan Pedagogik Guru di SDN Sadagori I Kota Cirebon Melalui IHT PAIKEM Berkelanjutan
}

\author{
Eva Resna Hendawati \\ SDN Karya Mulya I , JL. Kandang Perahu No.22 Kota Cirebon; \\ evaresnah03@gmail.com
}

\begin{abstract}
Abstrak. Penelitian Tindakan Sekolah bertujuan untuk Meningkatkan kemampuan pedagogik guru melalui In House Training Pembelajaran Aktif Inovatif Kreatif Efektif dan Menyenangkan (PAIKEM), kegiatan ini dilakukan berdasarkan hasil supervisi akademik yang diperoleh hasil, 35\% guru sudah melakukan pembelajaran secara aktif, dan $65 \%$ pembelajarannya berbasis konvensional, yang mengakibatkan pasifnya siswa dalam pembelajaran dan juga kurang berkembangnya potensi siswa seperti, inovatif, kreatif dan menyenangkan. PAIKEM merupakan pembelajaran yang berpusat pada siswa, yang mengembangkan potensi, gagasan dan kreativitas. Tindakan dilakukan dalam dua siklus, yang setiap siklusnya terdiri dari empat tahapan yaitu Perencanaan, Pelaksanaan, Pengamatan dan Refleksi. Hasil pengamatan dan refleksi pada siklus I mengindikasikan bahwa baru tiga dari empat belas guru telah mampu mengaktifkan siswa,menggunakan lembar kerja,dan memberikan reaward ,sedangkan sebelas guru baru mengaktifkan siswa dan menggunakan reward, artinya pemahaman guru tentang PAIKEM kurang. Pada siklus II, hasil pengamatan dan refleksi menunjukkan terjadinya peningkatan dalam pembelajaran dengan menggunakan pembelajaran aktif,efektif ,kreatif ,namun belum inovatif. Sehingga peneliti menyimpulkan meningkatnya pemahaman guru tentang PAIKEM dan penggunaannya pada pengembangan pembelajaran dalam penyusunan RPP,meningkatnya kemampuan guru pada pengembangan PAIKEM dalam penyusunan RPP dan adanya upaya dari guru untuk lebih meningkatkan profesionalismenya dalam penyusunan perencanaan pembelajaran, ditunjukkan dengan aktivitas guru dalam kegiatan KKG sekolah.
\end{abstract}

Kata Kunci: PAIKEM, IHT, Kompetensi Pedagogik

Abstract. School Action Research to improve teacher pedagogical skills through In House Effective and Enjoyable Creative Innovative Learning Learning Training (PAIKEM), this activity is based on academic supervision results that get results, $35 \%$ of teachers have been able to use learning actively, and $65 \%$ of learning is conventionally based, who try to be passive students in learning and also lack of developing the potential of students such as, innovative, creative and fun. PAIKEM is student-centered learning, which develops potential, creativity and collaboration. Actions carried out in two cycles, each cycle

Caruban: Jurnal Ilmiah Pendidikan Dasar 3(1), 52-67, Januari 2020

DOI: http://dx.doi.org/10.33603/.v3i1.3194, p-ISSN 2615-1391, e-ISSN 2620-3219

CProdi PGSD Universitas Swadaya Gunung Jati 
consisting of four stages, namely Planning, Implementation, Observation and Reflection. The results of observations and reflections in the first cycle studied three of the fourteen teachers that have enabled students, used worksheets, and provided reawards, while eleven new teachers activated students and used prizes, looking for teachers for less PAIKEM. In the second cycle, the results of observation and reflection showed an increase in learning by using active, effective, creative, but not yet innovative learning. How to improve the ability of teachers to develop lesson plans. Improve the ability of teachers to develop lesson plans. The efforts of the teacher to increase professionalism in learning planning, discuss with the teacher's activities in the school KKG activities.

Keywords: PAIKEM, IHT, Pedagogic Competence

\section{Pendahuluan}

Begitu sangat strategisnya kedudukan guru sebagai tenaga profesional, di dalam Undang-Undang Republik Indonesia Nomor 14 Tahun 2005 tentang Guru dan Dosen, tepatnya Bab III Pasal 7, diamanatkan bahwa profesi guru merupakan bidang pekerjaan khusus yang dilaksanakan berdasarkan prinsip sebagai berikut: (a) memiliki bakat, minat, panggilan jiwa, dan idealisme; (b) memiliki komitmen untuk meningkatkan mutu pendidikan, keimanan, ketakwaan, dan akhlak mulia (c) memiliki kualifikasi akademik dan latar belakang pendidikan sesuai dengan bidang tugas; (d) memiliki kompetensi yang diperlukan sesuai dengan bidang tugas; (e) memiliki tanggung jawab atas pelaksanaan tugas keprofesionalan; (f) memperoleh penghasilan yang ditentukan sesuai dengan prestasi kerja.

Peraturan Menteri Pendidikan Nasional (Permendiknas) Nomor 13 Tahun 2007 tentang Standar Kepala Sekolah menegaskan bahwa salah satu kompetensi yang harus dimiliki seorang kepala sekolah adalah kompetensi supervisi. Berdasarkan Permendiknas tersebut berarti seorang kepala sekolah harus kompeten dalam melakukan supervisi akademik terhadap guru-guru yang dipimpinnya.Demikian juga Perturan Menteri Pendidikan Nasional (Permendiknas) Nomor 16 Tahun 2007 tentang kompetensi Guru, khususnya kompetensi Pedagogik,yaitu kompetensi guru dalam mengelole Pembelajaran peserta didik.Antara lain menguasai karakteristik peserta didik, dan seterusnya. PAIKEM singkatan dari Pembelajaran Aktif,Inovatif, Kreatif,Efektif dan Menyenangkan Namun, pada kenyataannya, masih banyak temuan khususnya di sekolahyang peneliti pimpin yaitu SDN

Caruban: Jurnal Ilmiah Pendidikan Dasar 3(1), 52-67, Januari 2020

DOI: http://dx.doi.org/10.33603/.v3i1.3194, p-ISSN 2615-1391, e-ISSN 2620-3219

CProdi PGSD Universitas Swadaya Gunung Jati 
Sadagori 1 terutama yang menjadi sasaran dari supervisi akademik,lebih diarahkan pada peningkatan kualitas pembelajaran. Ada beberapa hal yang menjadi sorotan peneliti ketika supervisi dilakukan di semua kelas antara lain : 1) Pembelajaran pada umumnya masih terpusat pada guru 2) Hampir semua kompetensi dasar dilaksanakan dengan konvensional 3) Siswa tidak berani mengemukakan pendapat, bertanya, dan kesannya pembelajaran hampir disemua kelas membuat siswa bosan 4) Hampir disemua kelas tidak ada pajangan dan alat peraga tidak digunakan padahal alat peraga di sekolah sudah ada 5) Guru dalam melaksanakan Kegiatan Belajar Mengajar, sebagian besar tidak mau peduli dengan masalah metode, siswa hanya disuruh duduk, dengar, catat, dan hapal, istilah populernya terkenal dengan sebutan DDCH. Hal tersebut dapat terjadi dikarenakan, guru dari waktu ke waktu dalam melaksanakan pembelajarannya hanya menggunakan metode ceramah, yang dianggap tidak merepotkan dan praktis. Pembelajaran tidak menarik,monoton dan tidak menantang.

Berdasarkan permasalahan di atas maka peneliti mencoba mengadakan penelitian dalam melaksanakan tindak lanjut supervisi akademik, dengan judul "Peningkatan Kemampuan Pedagogik Guru di SDN Sadagori I Kota Cirebon Melalui IHT Paikem Berkelanjutan. Rumusan masalah penelitian ini sebagai berikut: Apakah IHT PAIKEM berkelanjutan sebagai tindak lanjut dari supervisi akademik dapat meningkatkan kemampuan dan kinerja guru SDN Sadagori I dalam mengajar?

Bagaimana langkah penerapan IHT PAIKEM Berkelanjutan agar meningkatkan kemampuan dan kinerja guru SDN Sadagori I dalam proses pembelajaran? Sedangkan tujuan yang akan dicapai dari penelitian ini adalah nengetahui tindakan IHT PAIKEM dalam meningkatkan kemampuan dan kinerja guru dalam pembelajaran di SD Negeri Sadagori I Kota Cirebon, sebagai tindak lanjut supervisi akademik. Mengkaji dan mendeskripsikan tindakan IHT PAIKEM dalam meningkatkan kemampuan dan kinerja guru di SD Negeri Sadagori I Kota Cirebon, sebagai tindak lanjut dari supervisi akademik. Jika tindakan itu dilakukan manfaatnya, pembelajaran akan berpusat pada guru,kreatif,inovatif ,menantang dan menyenangkan

Caruban: Jurnal Ilmiah Pendidikan Dasar 3(1), 52-67, Januari 2020

DOI: http://dx.doi.org/10.33603/.v3i1.3194, p-ISSN 2615-1391, e-ISSN 2620-3219

CProdi PGSD Universitas Swadaya Gunung Jati 
Metode

Penelitian tindakan sekolah ini dilaksanakan untuk memperoleh gambaran tentang IHT PAIKEM Berkelanjutan Dalam Supervisi Akademik Kepala Sekolah Untuk Meningkatkan Kemampuan dan Kinerja Guru di SDN Sadagori 1 Kota Cirebon".Penelitian ini dilakukan di SDN Sadagori I Kota Cirebon,dan waktu penelitian dilakukan pada semester pertama tahun pelajaran 2017, yaitu pada bulan Januari sampai dengan Juni 2015. Alur penelitian terdiri dari dua siklus. Setiap siklus terdiri dari dua kali pertemuan ,dan setiap siklus dilaksanakan dalam empat tahapan, yaitu: (1) perencanaan, (2) pelaksanaan tindakan, (3) observasi/pengamatan, dan (4) refleksi.Teknik Pengumpulan data yang digunakan dalam penelitian ini menggunakan observasi,angket,wawancara dan produk. Penelitian tindakan kelas ini menggunakan metode deskripsi kualitatif. Prosedur penelitian ini berdasarkan model Kemmis dan Taggart.

\section{Hasil dan Pembahasan}

Penelitian ini terdiri dari dua siklus, masing-masing siklus terdiri dari tahap perencanaan, tahap pelaksanaan, tahap pengamatan, dan tahap refleksi. Permasalahan yang belum dapat dipecahkan pada siklus pertama, direfleksikan untuk mencari penyebabnya. Selanjutnya peneliti merencanakan berbagai langkah perbaikan untuk ditetapkan pada siklus kedua.

\section{Siklus I}

\section{Tahap Perencanaan}

Pada tahap ini peneliti akan merumuskan hal-hal sebagai berikut.

1. Menyusun program IHT.

2. Menyiapkan materi yang berkaitan dengan PAIKEM.

3. Menyiapkan instrument alat ukur keberhasilan.

4. Menyiapkan rancangan RPP yang berbasis PAIKEM.

5. Menyiapkan fasilitas yang berkaitan dengan IHT PAIKEM.

\section{Tahap Pelaksanaan}

Pada tahap ini peneliti melakukan hal-hal sebagai berikut. Pada pelaksanaan siklus pertama 
1. Peneliti dan pengawas menyampaian materi yang berkaitan dengan PAIKEM.

2. Guru - guru berdiskusi dan mengevaluasi diri dalam melaksanakan pembelajaran.

3. Pembuatan rencana pembelajaran yang berbasisi PAIKEM.

4. Peneliti selaku kepala sekolah menugaskan beberapa guru untuk melaksanakan pembelajaran dengan rencana pembelajaran yang sudah di diskusikan berbasis PAIKEM.

5. Pelaksanaan pembelajaran yang dilakukan enam orang guru secara bertahap ,dengan menngunakan RPP yang telah dibahas dan berbasis PAKEM , pengamat peneliti sendiri dan dua orang pengawas.

\section{Tahap Pengamatan}

Pengamatan ini dilakukan oleh peneliti itu sendiri dan dua orang Pengawas. Mengamati hal - hal berikut :

1. Mengamati pelaksanaan pembelajaran pengembangan pelaksanaan PAIKEM.

2. Mencatat apa yang dilakukan guru pada saat pembelajaran.

3. Guru sudah mengaktifkan siswa,menggunakan lembar kerja,dan memberikan reaward.

\section{Tahap Refleksi}

Dalam tahap refleksi pada siklus I,penulis mencatat sebagai berikut . Berdasarkan hasil temuan penulis di lapangan, penyebab kurangnya pemahaman guru tentang pengembangan PAIKEM antara lain adalah kurangnya pemahaman terhadap pelaksanaan pembelajaran . Oleh karena itu, konsep PAIKEM yang tepat harus dipahami terlebih dahulu oleh guru, sebelum ke pelaksanaan a.Pengembangan/penyusunan PAIKEM pencapaian kompetensi.

Selama kegiatan siklus 1 berlangsung, dilaksanakan observasi internal (penulis sebagai observer) dan observasi eksternal (oleh dua orang pengawas sebagai observer). Berdasarkan hasil observasi tersebut diperoleh data ,rata rata prosentase pemahaman guru tentang PAIKEM dan penggunaannya dalam pengembangan PAIKEM pencapaian kompetensi mencapai 32,00\%, 
hal ini berarti kualifikasi pemahaman guru tentang PAIKEM kurang, seperti tampak pada Tabel 1 berikut ini:

Tabel 1. ProsentasePemahaman Guru tentang PAIKEM

\begin{tabular}{|c|c|c|c|}
\hline No. & Aspek yang diobservasi & Prosentase & Ket \\
\hline 1. & Pehamaman Guru tentang PAIKEM & $40,00 \%$ & \\
\hline 2. & Pehamaman Guru tentang Penggunaan PAIKEM & $40,00 \%$ & \\
\hline 3. & $\begin{array}{l}\text { Pehamaman Guru tentang ketepatan penulisan/ } \\
\text { pengembangan PAIKEM }\end{array}$ & $40,00 \%$ & \\
\hline 4. & $\begin{array}{l}\text { Pehamaman Guru tentang sistematika } \\
\text { pengembangan pelaksanaan PAIKEM }\end{array}$ & $20,00 \%$ & \\
\hline 5. & Pehamaman Guru tentang unsur unsur PAIKEM & $20,00 \%$ & \\
\hline
\end{tabular}

Hasil penelitian pemahaman guru tentang PAIKEM baru mencapai $40 \%$, artinya masih ada guru yang belum benar-benar memahami PAIKEM dan penerapannya. Sedangkan pemahaman guru dalam sistematika pengembangan pelaksnaan PAIKEM masih kurang (20\%), artinya rata-rata guru belum mampu untuk mengembangkan PAIKEM dalam pembelajaran.

\section{Kemampuan Guru dalam Pengembangan PAIKEM}

Observasi terhadap kemampuan guru , dilaksanakan selama kegiatan Siklus I berlangsung oleh observer internal dan observer eksternal. Hasil observasi terhadap kemampuan guru dalam pengembangan PAIKEM diperoleh data rata rata prosentase kemampuan guru dalam pengembangan PAIKEM baru mencapai 36,25\%, artinya kualifikasi pemahaman guru tentang PAIKEM kurang, seperti tampak pada tabel 2 berikut:

Tabel 2. Prosentase Pemahaman Guru tentang Pengembangan PAIKEM

\begin{tabular}{llll}
\hline No. & Aspek yang diobservasi & Prosentase & Ket \\
\hline 1. & unsur PAIKEM dikembangkan sesuai & $20,00 \%$ \\
& dengan karakteristik peserta didik & & \\
2. & PAIKEM dikembangkan sesuai dengan & $20,00 \%$ \\
& karakteristik potensi sekolah & & \\
\hline
\end{tabular}

Caruban: Jurnal Ilmiah Pendidikan Dasar 3(1), 52-67, Januari 2020

DOI: http://dx.doi.org/10.33603/.v3i1.3194, p-ISSN 2615-1391, e-ISSN 2620-3219

CProdi PGSD Universitas Swadaya Gunung Jati 


\begin{tabular}{|c|c|c|c|}
\hline No. & Aspek yang diobservasi & Prosentase & Ket \\
\hline 3. & $\begin{array}{l}\text { PAIKEM dikembangkan sesuai dengan } \\
\text { karakteristik tema }\end{array}$ & $40,00 \%$ & \\
\hline 4. & $\begin{array}{l}\text { PAIKEM dikembangkan sesuai dengan } \\
\text { satuan pendidikan }\end{array}$ & $40,00 \%$ & \\
\hline 5. & $\begin{array}{l}\text { PAIKEM dikembangkan sesuai dengan } \\
\text { kepentingan (urgensi) }\end{array}$ & $50,00 \%$ & \\
\hline 6. & $\begin{array}{l}\text { PAIKEM dikembangkan } \\
\text { berkesinambungan (kontinu) }\end{array}$ & $50,00 \%$ & \\
\hline 7. & $\begin{array}{l}\text { PAIKEM dikembangkan terukur dan } \\
\text { dapat diobservasi }\end{array}$ & $40,00 \%$ & \\
\hline 8. & $\begin{array}{l}\text { PAIKEM dikembangkan dengan Jelas } \\
\text { dan tepat }\end{array}$ & $30,00 \%$ & \\
\hline
\end{tabular}

Kurangnya kemampuan guru dalam mengembangkan PAIKEM sesuai karakteristik peserta didik (20\%) dan karakteristik potensi daerah (20\%), karena mereka (guru) kurang memahami PAIKEM dan penerapannya dalam mengembangkan PAIKEM berdasarkan aspek pengetahuan, keterampilan dan sikap. guru kurang memahami unsur PAIKEM yang tepat sesuai dengan tingkat berfikir siswa, rata-rata mengembangkan PAIKEM mengambil dari kriteria buku pegangan guru . ketercapaian kemampuan guru dalam mengembangkan PAIKEM sesuai karakteristik tema dan satuan pendidikan, baru mencapai 40\% (kulifikasi cukup).

Kemampuan guru dalam mengembangkan PAIKEM sesuai dengan kepentingan dan kontinu sudah mencapai 50\% (kulifikasi cukup), disini sudah nampak adanya usaha dari guru untuk mengembangkan PAIKEM sesuai dengan kepentingan dan adanya kekontinuan dalam pengembangannya. Guru mengembangkan PAIKEM melalui analisis terhadap kompetensi inti (KI ) dan kompetensi dasar (KD) tetapi belum maksimal. berdasarkan hasil observasi, PAIKEM dikembangkan hanya menganalisis KI /KD (standar isi) saja, sedangkan standar kompetensi lulusan (SKL demikian juga dengan tingkat/keterukuran PAIKEM, pengembangannya baru mencapai $40 \%$ (kualifikasi cukup), dan ketepatan

Caruban: Jurnal Ilmiah Pendidikan Dasar 3(1), 52-67, Januari 2020

DOI: http://dx.doi.org/10.33603/.v3i1.3194, p-ISSN 2615-1391, e-ISSN 2620-3219

CProdi PGSD Universitas Swadaya Gunung Jati 
serta kejelasan PAIKEM baru mecapai 30\% (kualifikasi kurang), hal ini sangat erat kaitannya dengan pemahaman guru tentang PAIKEM dan penggunaannya/penerapannya. jadi jelaslah bahwa guru belum mampu mengembangkan PAIKEM sesuai kriteria PAIKEM yang diharapkan (baik), sehingga keberhasilan pembelajaran juga belum maksimal.

\section{Aktivitas Guru dalam Kegiatan Pengembangan PAIKEM}

Aktivitas guru kelas dalam kegiatan pengembangan PAIKEM merupakan salah satu aspek yang diobservasi, hal tersebut peneliti lakukan karena peneliti ingin mengukur sejauh mana guru termotivasi untuk mengembangkan PAIKEM dan menyusun RPP sendiri.

Pengamatan (observasi) terhadap aktivitas guru dikelompok KKG yakni kegiatan pengembangan PAIKEM, diperoleh hasil data rata rata prosentase aktivitas guru mencapai 80,00 \% dengan kualifikasi sangat baik, mereka menyambut baik program kegiatan pengembangan PAIKEM ini, seperti yang terlihat pada tabel 3 berikut ini:

Tabel 3. Prosentase Aktivitas Guru dalam Kegiatan Pengembangan PAIKEM

\begin{tabular}{llll}
\hline No. & Aspek yang diobservasi & Prosentase & Ket \\
\hline 1. & Disiplin & $90,00 \%$ & \\
2. & Tanggung Jawab & $80,00 \%$ & \\
3. & Kerjasama & $80,00 \%$ & \\
4. & Antusias/serius & $90,00 \%$ & \\
5. & Keterlibatan dalam diskusi & $60,00 \%$ & \\
\hline
\end{tabular}

Disiplin, tanggungjawab, kerjasama dan keseriusan guru dalam kegiatan pengembangan PAIKEM sangat baik, mereka menyadari pentingnya kegiatan tersebut untuk meningkatkan profesionalisme mereka dalam menyusun perencanaan pembelajaran dan pengelolaan pembelajaran. Hanya dalam keterlibatan dalam diskusi baru mencapai 60\% (kualifikasi baik), berdasarkan hasil pengamatan masih ada guru yang belum berani mengemukakan pendapatnya dalam kegiatan diskusi selama kegiatan di KKG berlangsung.

Caruban: Jurnal Ilmiah Pendidikan Dasar 3(1), 52-67, Januari 2020

DOI: http://dx.doi.org/10.33603/.v3i1.3194, p-ISSN 2615-1391, e-ISSN 2620-3219

CProdi PGSD Universitas Swadaya Gunung Jati 
Berdasarkan data-data hasil observasi tersebut, diperoleh temuan bahwa pemahaman guru tentang PAIKEM dan penggunaannya dalam pengembangan PAIKEM masih kurang (32,00 \%). demikian juga kemampuan guru dalam pengembangan PAIKEM masih kurang $(36,25 \%)$. data hasil temuan pada kegiatan siklus I, menjadi dasar/acuan bagi peneliti untuk melaksanakan kegiatan siklus II.

\section{Siklus II}

\section{Pemahaman Guru tentang PAIKEM dan Penggunaannya dalam Pengembangan pembelajaran}

Berdasarkan temuan pada Siklus I bahwa pemahaman guru dalam pengembangan PAIKEM kurang (32,00 \%), maka peneliti melakukan tindakan penelitian Siklus II. Selama pelaksanaan kegiatan Siklus II, yaitu kegiatan KKG untuk meningkatkan pemahaman guru tentang PAIKEM dan penggunaannya dalam pengembangan PAIKEM, dilakukan observasi seperti pada siklus I. Hasil observasi diperoleh data rata rata prosentase tentang PAIKEM dan penggunaannya dalam pengembangan PAIKEM meningkat dari 32,00 \% menjadi 68,00 \% dengan kualifikasi baik, seperti pada Tabel 4 berikut ini:

Tabel 4. Prosentase Pemahaman Guru tentang PAIKEM dan Penggunaannya dalam Pengembangan pembelajaran

\begin{tabular}{lll}
\hline No. & Aspek yang diobservasi & Prosentase \\
\hline 1. & Pehamaman Guru dalam pengembangan PAIKEM & $80,00 \%$ \\
2. & Pehamaman Guru tentang Penggunaan PAIKEM & $80,00 \%$ \\
3. & Pehamaman Guru tentang ketepatan penulisan/ & $60,00 \%$ \\
& $\begin{array}{l}\text { pengembangan PAIKEM } \\
\text { 4. }\end{array}$ & \\
& $\begin{array}{l}\text { Pehamaman Guru tentang sistematika } \\
\text { 5. }\end{array}$ & \\
\hline
\end{tabular}

Disini tampak adanya perubahan pemahaman guru dalam pengembangan PAIKEM meningkat cukup tinggi, mereka mulai memahami bahwa pengembangan PAIKEM sangat penting, karena akan mudah untuk menilai

Caruban: Jurnal Ilmiah Pendidikan Dasar 3(1), 52-67, Januari 2020

DOI: http://dx.doi.org/10.33603/.v3i1.3194, p-ISSN 2615-1391, e-ISSN 2620-3219

CProdi PGSD Universitas Swadaya Gunung Jati 
tingkat ketercapaian penguasaan siswa terhadap tema. Demikian juga adanya perubahan yang cukup signifikan terhadap kemampuan guru dalam ketepatan, sistematika dan pengembangan PAIKEM, mereka menyadari, bahwa pengembangan PAIKEM dengan tepat dan sistematis akan memudahkan mereka dalam mengelola pembelajaran sehingga siswa lebih terarah dalam mencapai target/kompetensi yang harus dikuasainya.

\section{Kemampuan Guru dalam Pengembangan PAIKEM}

Hasil observasi dalam Siklus II terhadap kemampuan guru tentang pengembangan PAIKEM dalam penyusunan RPP meningkat, yakni dari 36,25\% (Siklus I) menjadi 65,00\%, seperti tampak pada Tabel 5 berikut:

Tabel 5. Prosentase Kemampuan Guru dalam Pengembangan PAIKEM

\begin{tabular}{|c|c|c|c|}
\hline No. & Aspek yang diobservasi & Prosentase & Ket \\
\hline 1. & $\begin{array}{l}\text { PAIKEM dikembangkan sesuai dengan } \\
\text { karakteristik peserta didik }\end{array}$ & $60,00 \%$ & \\
\hline 2. & $\begin{array}{l}\text { PAIKEM dikembangkan sesuai dengan } \\
\text { karakteristik potensi daerah }\end{array}$ & $60,00 \%$ & \\
\hline 3. & $\begin{array}{l}\text { PAIKEM dikembangkan sesuai dengan } \\
\text { karakteristik tema }\end{array}$ & $70,00 \%$ & \\
\hline 4. & $\begin{array}{l}\text { PAIKEM dikembangkan sesuai dengan } \\
\text { satuan pendidikan }\end{array}$ & $70,00 \%$ & \\
\hline 5. & $\begin{array}{l}\text { PAIKEM dikembangkan sesuai dengan } \\
\text { kepentingan (urgensi) }\end{array}$ & $70,00 \%$ & \\
\hline 6. & $\begin{array}{l}\text { PAIKEM dikembangkan berkesinambungan } \\
\text { (kontinu) }\end{array}$ & $60,00 \%$ & \\
\hline 7. & $\begin{array}{l}\text { PAIKEM dikembangkan terukur dan dapat } \\
\text { diobservasi }\end{array}$ & $80,00 \%$ & \\
\hline 8. & $\begin{array}{l}\text { PAIKEM dikembangkan dengan jelas dan } \\
\text { tepat }\end{array}$ & $60,00 \%$ & \\
\hline
\end{tabular}

Berdasarkan hasil observasi pada kegiatan siklus ii tersebut di atas, kemampuan guru dalam mengembangkan PAIKEM sesuai karakteristik peserta didik dan karakteristik potensi daerah mengalami peningkatan yang cukup baik, mereka mulai menyadari bahwa PAIKEM harus dikembangkan 
sesuai dengan tingkat berfikir siswa (peserta didik) bukan tingkat berfikir guru. selain itu mereka menyadari bahwa PAIKEM harus dikembangkan sesuai dengan karakteristik potensi daerah, hal ini sesuai dengan tujuan penyusunan KTSP yang merupakan hak otonomi sekolah.

Demikian juga dengan kemampuan guru dalam mengembangkan PAIKEM sesuai karateristik mata pelajaran dan tingkat satuan pendidikan meningkat. mereka mulai memahami bahwa PAIKEM harus dikembangkan sesuai dengan karakteristik tema, jadi dalam mengembangkan PAIKEM harus memperhatikan tuntutan atau standar yang ingin dicapai dari mata pelajaran tesebut. demikian juga dengan pengembangan PAIKEM harus sesuai tingakt satuan pendidikan, karena tiap satuan pendidikan memiliki karakteristik yang berbeda, dan memiliki tuntutan yang berbeda terhadap lulusannya.

Kemampuan guru dalam mengembangkan PAIKEM sesuai kepentingan, berkesinambungan, terukur dan dapat diobservasi, serta tepat dan jelas, meningkat. Hal ini berdasarkan hasil observasi, bahwa guru mulai memahami PAIKEM dan penerapannya serta guru memahami bahwa indiktator harus dibuat berdasarkan kepentingan dan berkesinambungan melalui kegiatan menganalisis keterkaitan antar kompetensi dasar dan antar standar kompetensi, selain itu juga melalui pemetaan KI , KD.

\section{Aktivitas Guru dalam Kegiatan Pengembangan PAIKEM}

Observasi terhadap seluruh aktivitas guru dalam kegiatan KKG pada Siklus II, yakni kegiatan pengembangan PAIKEM, aktivitas guru mengalami peningkatan yang signifikan, mereka (guru) bekerjasama dalam kelompok dengan penuh tanggung jawab dan disiplin, serta terlibat secara aktif dalam diskusi kelompok seperti yang terlihat pada tabel 6 berikut ini.

Tabel 6. Prosentase Aktivitas Guru dalam Kegiatan Pengembangan PAIKEM

\begin{tabular}{llll}
\hline No. & Aspek yang diobservasi & Prosentase & Ket \\
\hline 1. & Disiplin & $90,00 \%$ & \\
2. & Tanggung Jawab & $90,00 \%$ & \\
3. & Kerjasama & $90,00 \%$ & \\
\hline
\end{tabular}

Caruban: Jurnal Ilmiah Pendidikan Dasar 3(1), 52-67, Januari 2020

DOI: http://dx.doi.org/10.33603/.v3i1.3194, p-ISSN 2615-1391, e-ISSN 2620-3219

CProdi PGSD Universitas Swadaya Gunung Jati 


\begin{tabular}{llll}
\hline No. & Aspek yang diobservasi & Prosentase & Ket \\
\hline 4. & Antusias/serius & $90,00 \%$ & \\
5. & Keterlibatan dalam diskusi & $80,00 \%$ & \\
\hline
\end{tabular}

Berdasarkan data tersebut di atas, tampak bahwa rata rata prosentase aktivitas guru kelas rendah dan guru kelas tinggi dalam kegiatan pengembangan PAIKEM meningkat dari 80,00\% (siklus I ) menjadi 88,00 \%.Keterlibatan mereka dalam diskusi sangat baik, mereka cukup termotivasi untuk terlibat secara emosional dan kegiatan pengembangan PAIKEM tersebut, mereka menyadari bahwa kegiatan pengembangan PAIKEM sangat penting bagi mereka dalam meningkatkan profesionalismenya.

Dalam pembahasan masalah ini, peneliti membandingkan hasil kegiatan yang telah dilaksanakan pada Siklus I dan Siklus II, tujuannya adalah untuk mengetahui perubahan yang terjadi setelah kedua siklus tersebut dilalui/dilaksanakan. Berikut ini merupakan perbandingan-perbandingan hasil kegiatan Siklus I dan Siklus II.

\section{Perkembangan Pemahaman Guru tentang PAIKEM dan Penggunaannya dalam Pengembangan Pembelajaran}

Berdasarkan hasil temuan peneliti di lapangan, bahwa guru masih ada yang belum memahami tentang pengembangan PAIKEM dalam penyusunan RPP, melalui kegiatan bimbingan dan pembinaan yang dilaksanakan oleh peneliti dengan kajian pengembangan PAIKEM terlihat ada peningkatan pemahaman mereka (guru) dalam pengembangan PAIKEM tersebut, dari $32,00 \%$ menjadi $68,00 \%$, tampak seperti pada tabel 7 berikut ini

Tabel 7. Prosentase Pemahaman Guru tentang PAIKEM dan Penggunaannya dalam Pengembangan pembelajaran

\begin{tabular}{llll}
\hline No. & Aspek yang diobservasi & Siklus I & Siklus II \\
\hline 1. & $\begin{array}{l}\text { pemahaman guru dalam pengembangan } \\
\text { PAIKEM }\end{array}$ & $40,00 \%$ & $80,00 \%$ \\
2. & $\begin{array}{l}\text { pemahaman guru tentang penggunaan } \\
\text { PAIKEM }\end{array}$ & $40,00 \%$ & $80,00 \%$ \\
\hline
\end{tabular}

Caruban: Jurnal Ilmiah Pendidikan Dasar 3(1), 52-67, Januari 2020

DOI: http://dx.doi.org/10.33603/.v3i1.3194, p-ISSN 2615-1391, e-ISSN 2620-3219

CProdi PGSD Universitas Swadaya Gunung Jati 


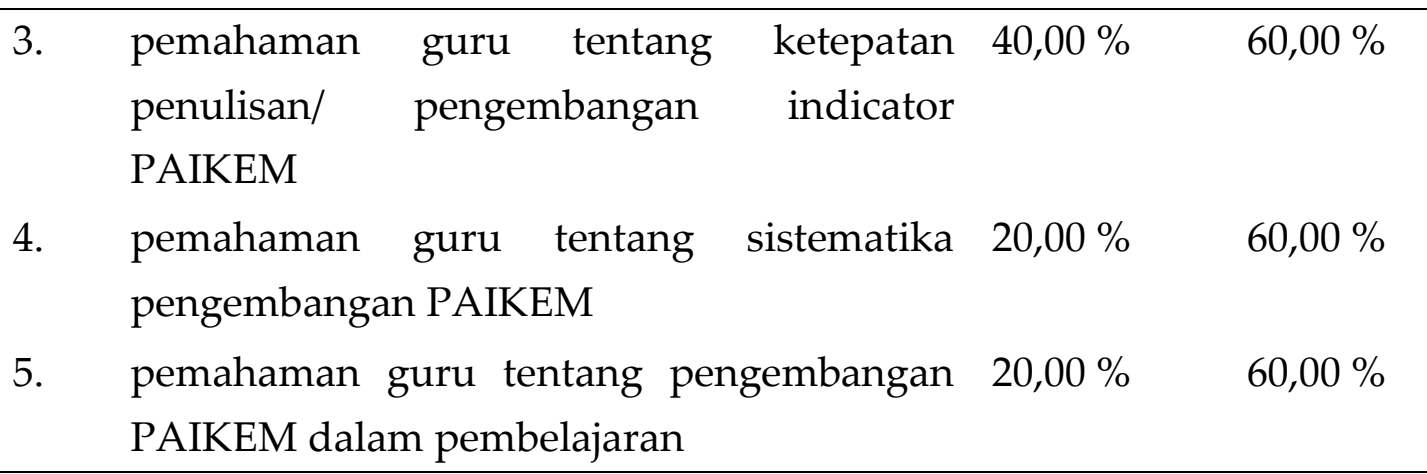

Agar lebih jelas data pada tabel di atas, dapat kita lihat dalam bentuk grafik 1 berikut:

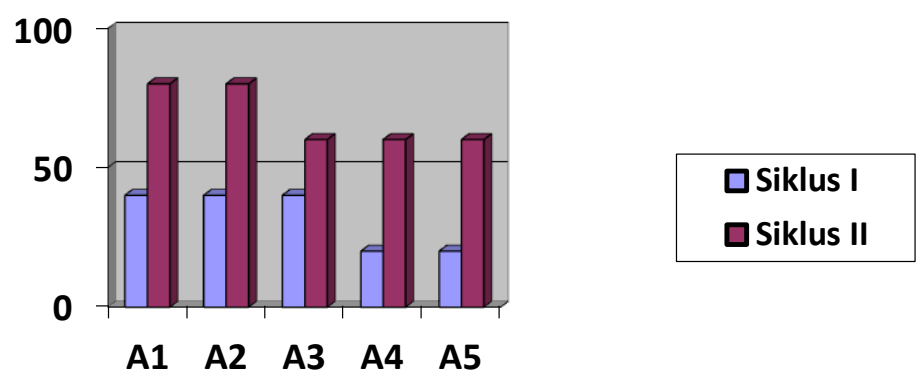

Grafik 1. Prosentase Pemahaman Guru tentang PAIKEM dan Penggunaannya dalam Pengembangan Pembelajaran

\section{Perkembangan Pemahaman Guru tentang Pengembangan PAIKEM}

Rata rata prosentase pemahaman guru tentang pengembangan PAIKEM dalam penyusunan RPP terlihat ada peningkatan, seperti tampak pada Tabel 8 berikut ini:

Tabel 8. Prosentase Pemahaman Guru tentang Pengembangan PAIKEM

\begin{tabular}{llll}
\hline No. & Aspek yang diobservasi & Siklus I & Siklus II \\
\hline 1. & PAIKEM dikembangkan sesuai dengan & $20,00 \%$ & $60,00 \%$ \\
& karakteristik peserta didik & & \\
\hline 2. & PAIKEM dikembangkan sesuai dengan & $20,00 \%$ & $60,00 \%$ \\
& karakteristik potensi daerah & & \\
\hline 3. & PAIKEM dikembangkan sesuai dengan & $40,00 \%$ & $70,00 \%$ \\
\hline
\end{tabular}


\begin{tabular}{lllll}
\hline 4. & PAIKEM dikembangkan sesuai dengan $40,00 \%$ & $70,00 \%$
\end{tabular} satuan pendidikan

\begin{tabular}{|c|c|c|c|}
\hline 5. & $\begin{array}{l}\text { PAIKEM dikembangkan sesuai dengan } \\
\text { kepentingan (urgensi) }\end{array}$ & $50,00 \%$ & $70,00 \%$ \\
\hline 6. & $\begin{array}{l}\text { PAIKEM dikembangkan } \\
\text { berkesinambungan (kontinu) }\end{array}$ & $50,00 \%$ & $60,00 \%$ \\
\hline 7. & $\begin{array}{l}\text { PAIKEM dikembangkan terukur dan } \\
\text { dapat diobservasi }\end{array}$ & $40,00 \%$ & $80,00 \%$ \\
\hline 8. & $\begin{array}{l}\text { PAIKEM dikembangkan dengan jelas dan } \\
\text { tepat }\end{array}$ & $30,00 \%$ & $60,00 \%$ \\
\hline
\end{tabular}

Hal ini dapat terlihat dari sajian grafik 2, sebagai pembanding hasil kegiatan yang dilaksanakan pada Siklus I dan Siklus II tentang pemahaman guru dalam mengembangkan PAIKEM dalam menyusun RPP.

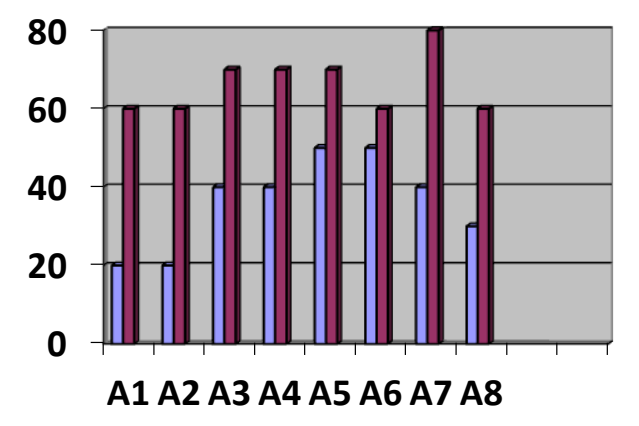

\begin{tabular}{|l|}
\hline 口Siklus I \\
पSiklus II \\
$\square A=$ Aspek \\
\hline
\end{tabular}

Grafik 2. Prosentase Pemahaman Guru tentang Pengembangan PAIKEM

\section{Perkembangan Aktivitas Guru dalam Kegiatan Pengembangan PAIKEM}

Perkembangan aktivitas guru dalam kegiatan pengembangan PAIKEM mengalami perubahan/peningkatan, hal tersebut dapat dilihat pada tabel 9 beikut ini:

Tabel 9. Prosentase Aktivitas Guru dalam Kegiatan Pengembangan PAIKEM

\begin{tabular}{llll}
\hline No. & Aspek yang diobservasi & Siklus I & Siklus II \\
\hline 1. & Disiplin & $90,00 \%$ & $90,00 \%$ \\
\hline 2. & Tanggung Jawab & $80,00 \%$ & $90,00 \%$ \\
\hline 3. & Kerjasama & $80,00 \%$ & $90,00 \%$ \\
\hline 4. & Antusias/serius & $90,00 \%$ & $90,00 \%$ \\
\hline
\end{tabular}




\begin{tabular}{llll}
\hline No. & Aspek yang diobservasi & Siklus I & Siklus II \\
\hline 5. & Keterlibatan dalam diskusi & $60,00 \%$ & $80,00 \%$ \\
\hline
\end{tabular}

Lebih jelasnya, perkembangan aktivitas guru dalam pengembangan dapat dilihat dari sajian grafik 3 berikut ini:
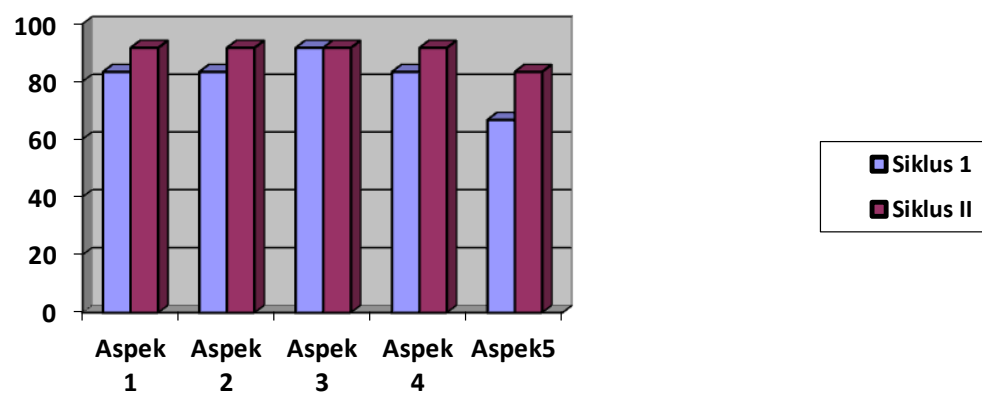

Grafik 3. Rata rata Prosentase Aktivitas Guru

\section{Simpulan}

Berdasarkan hasil pelaksanaan penelitian tindakan tentang upaya Kepala Sekolah dalam meningkatkan kemampuan guru dalam pengembangan PAIKEM melalui tindakan supervisi Akademik, maka peneliti dapat menarik kesimpulan sebagai berikut. Meningkatnya pemahaman guru tentang PAIKEM dan penggunaannya pada pengembangan pembelajaran dalam penyusunan RPP, meningkatnya kemampuan guru pada pengembangan PAIKEM dalam penyusunan RPP, adanya upaya dari guru untuk lebih meningkatkan profesionalismenya dalam penyusunan perencanaan pembelajaran, ditunjukkan dengan aktifitas guru dalam kegiatan KKG.

Dari simpulan tersebut, maka peneliti menyarankan peningkatan pemahaman guru tentang paikeum dan penggunaannya pada pengembangan PAIKEM untuk semua kelas, pembinaan dan Pembimbingan terhadap Guru dalam menyusun perencanaan ( RPP) dan pelaksanaan pembelajaran perlu terus ditingkatkan dan ditindak lajuti, peningkatan Profesionalisme guru melalui superviisi klinis harus dilakukan secara menyeluruh dan berkesinambungan, bukan untuk masalah PAIKEM saja. 


\section{Daftar Pustaka}

Akhmad Sudrajat (2008), Supervisi klinis untuk perbaikan pembelajaran, word press.com.

BSNP 2006, Panduan Penyusunan Kurikulum Tingkat Satuan Pendidikan Jenjang Pendidikan Dasar dan Pendidikan Menengah, Jakarta.

Dirjen PMPTK, 2007, Karya Tulis Ilmiah Laporan Hasil Penelitian, Pedoman

Penyusunan KTI pada Kegiatan Pengembangan Profesi Kepala Sekolah Sekolah.

Depdikbud (1996), Materi Pelatihan Supervisi dan Administrasi Pendidikan,Jakarta

Depdikbud (1996), Materi Pelatihan Supervisi dan Administrasi Pendidikan,Jakarta.

Depdiknas (2004), Pedoman Supervisi Pengajaran, Jakarta

Mulyasa (2005), Menjadi Guru Profesional,Bandung, Penerbit PT. Remaja Rosdakarya,

Ngalim Purwanto (2002), Administrasi dan Supervisi Pendidikan,BandungPenerbit Alfabeta.

Sugiyono (2005), Metode Penelitian Administrasi, Bandung, Penerbit Alfabeta. 